\title{
Fisheries women groups in Japan: a shift from well-being to entrepreneurship
}

\author{
Kumi Soejima ${ }^{1} \cdot$ Katia Frangoudes ${ }^{2}$ \\ Received: 28 October 2019 / Accepted: 8 November 2019 / Published online: 21 November 2019 \\ (C) The Author(s) 2019
}

\begin{abstract}
Women's groups in rural fishery areas were established in the mid-1950s. By 1959, they became integrated in local Fishery Cooperative Associations as parallel organizations. These Fisheries Cooperative Associations, established in 1948, represent all fishers in Japan, who are primarily men. The purpose of the women's groups was to provide well-being by improving the living conditions of families and communities. While men were busy building the production facilities and the cooperatives, women organized themselves to protect and improve the everyday life of families. From 1995 and the World Conference on Women in Beijing, China, some of these women groups ran economic entrepreneurial activities with the financial support of the State through the cooperatives. This new role of women's groups aims to improve the economic and social development and environment of families and communities facing depopulation problems who need to increase the number of young people. This paper examines the role of cooperative associations in rural, fishery communities and shows how these associations "handed over" the social responsibilities to the women groups who then developed their social skills and competences. Special emphasis is put on how the women groups changed their activity from social issues to environmental protection, promotion of fishery products, and to entrepreneurial activities. The paper also problematizes the difficulties the women met in order to get their contribution to the fisheries communities and industry recognized, as well as their status.
\end{abstract}

Keywords Fisheries women's group · Entrepreneurship · Wellbeing · Fisheries Cooperative Association · Japan

\section{Introduction}

In Japan, the first fisheries cooperatives appeared during the democratization process undertaken during the Meiji Era (1868-1912). During this time, the main objective of cooperatives was to remove the control of feudal power in fisheries (Kurihara 2008a). With the passing of the new Fisheries Law in 1948, Fisheries Cooperative Associations (FCAs) expanded to all coastal communities throughout Japan. During the period following World War II, men and FCAs were occupied

Kumi Soejima

soejima.kumi@gmail.com

Katia Frangoudes

Katia.Frangoudes@univ-brest.fr

1 National Fisheries University, 2-7-1 Nagatahonmachi, Shimonoseki City, Yamaguchi Prefecture 759-6595, Japan

2 Univ Brest, Ifremer, CNRS, UMR 6308, AMURE, IUEM, 29280 Plouzane, France with the reconstruction of the fishing fleet, infrastructure, and the whole production system. By contrast, women's activities during this reconstruction of Japan's fisheries were concentrated on supporting and sustaining their families and communities. These activities concentrated primarily on reducing expenses, feeding families, and improving living conditions in communities (Miki 2010). As a result of these gendered roles, women created their own fisheries groups, which became officially connected to FCAs as parallel groups in 1959.

Over the years, the actions and the valorization of women's contributions have changed. Activities designed to increase community cohesion became less visible and less valued. Caring of elderly people and recruiting young people to fishing communities also became less important compared with the more productive role of FCAs. Moreover, other types of activities took precedence such as environmental work, promoting fishery products, creating new products, as well as women's entrepreneurial activities.

The purpose of this paper is to explore the evolving role of women's groups in fishing communities in relation to the FCAs and examine women's motivations for shifting from 
social and environmental activities to economic activities. Greater emphasis on the groups' economic and entrepreneurial activities transformed not only women's individual situations but also the situation of the rural fishing communities. Therefore, this paper discusses the relation between women and men, especially regarding FCAs as male-dominated organizations, and their attitudes towards women, particularly towards the leaders of these women's entrepreneurial groups.

The data used in this article is coming from interviews and meetings of the national Umi Hito Kurashi Forum of women's entrepreneurial groups and literature and published sources, written sources.

\section{Perspectives: influence and power}

By raising the above questions, the paper also touches upon the issues of women's and men's relationships of power and influence, questions that have been of interest in most social sciences. Blau's (1964:117) defines power as:

abilities of persons and groups to impose their will on others despite resistance through deterrence either in the form of withholding, regularly supplied rewards, or in the form of punishment inasmuch, as the former or the latter constitute, in effect, a negative sanction.

Radtke and Stam (1994:3) write that such a way of looking at power relates to behavioral social exchanges and positivistic theories inspired by the Weberian way of looking at power where the subject plays an important role. Moss Kanter (1977) demonstrated how women and men in large corporations practiced their roles as leaders in different ways and with different impacts on women's and men's power relations. Women and men as individuals within certain structures with certain cultural expression were conceived differently.

Foucault (1980:98) wrote that:

power is employed and exercised through a net-like organization and not only do individuals circulate through its threads; they are always in the position of simultaneously undergoing and exercising this power. They are not only its inert or consenting target. They are always also elements of its articulation. In other words, individuals are the vehicles of power, not its point of application.

Foucault characterized power as regimes of power that occurred through a process of self-discipline or self-regulation. Such a view of power has challenged feminists who have often studied patriarchy or patriarchal power, including in fisheries (see for example Munk-Maden 1998). In feminist fishery research, focus has also been placed on the emancipatory role that changing institutions in a more gender inclusive direction can have, in which their internal structures allow room for women on the same terms as men and where women's voices can be heard.

\section{The background: Fisheries Cooperative Associations and men's domination}

Since their establishment, FCAs are the official representatives of fishers and everyone, women and men, youths and children, living in rural fishing communities. The FCAsystem is structured on three elements: community, territoriality, and livelihood rights (Ruddle and Akimichi 1984). The system is perceived as egalitarian, since the allocation of resources is built on equal distribution and little or no competition (Delaney and Yagi 2018; Barret and Okudaira 1995).

In some areas of the country, women perform marinerelated activities without being regular members of cooperatives. This is the case of the ama-san (women divers who harvest abalone) in Yamaguchi province. Women are represented by the head of the household; in other words, their husbands. Their husbands are the regular members of the cooperative and are the only ones allowed to discuss and decide how to regulate the activity and manage the stocks. This is the case even though equitable access to the resources for all members was recognized as a principle after 1945, when many fisheries families suffered from famine. Today, this system, based on "one-member in the FCA per household," has left women and young men in a lower position compared with older male fishers in terms of resource rights allocations. According to Delaney (2003), junior members are receiving less access than older members. Moreover, Nakamichi (2009) points out that men, since they are regular, full members, dominate FCAs and decision-making. As the years have gone by, this system has led to a significant increase in the number of elderly fishers.

Thanks to the 1948 Fisheries Cooperative Law, FCAs also dominate the economic and social life of fishing communities. The law made FCAs responsible for the improvement of the economic and social status of fishers and fisheries processing workers, and more particularly, for enhancing fisheries production capacity (Kurihara 2008b). The FCAs have also had financial functioned as banks, offering loans and savings services for their members (Delaney 2015; Makino 2011; Soejima 2009). However, their role as bank was abandoned in 2009.

There have been important updates related FCAs. For example, the Fisheries Basic Plan of 2017 gave the FCAs the task of "promoting women's participation in the fisheries sector." This task has been further developed in later plans by the Japanese 
authorities with the aim of "promot[ing] women's participation in every field" and especially increasing "women's role in economic development" (Cabinet Office 2015, Gender Equality Bureau Cabinet Office. 2016). The 2017 plan instructs the 942 FCAs to not only promote women's economic development, but also to start new activities in communities (Statistics of FCA, Fisheries Agency 2017). This has led to the setting up of entrepreneurial activities for women.

One interesting question to discuss is whether FCAs will be able to achieve these new objectives and tasks, since women are not regular members, and because FCA membership still is based on the principle of one member per household. As it stands, this principle is an advantage for men, since men are most often indentified as heads of the household and thus more welcome as regular members of the FCAs. Up until now, Japanese society has also given greater value to men's fishing over women's fisheries work. It is now important to consider if current FCA membership rules, and the disproportionate value given to men's fishing, can change and make room for women to be equal participants in FCAs and the fisheries. Are men in fishing communities now willing to open FCA membership positions for women and recognize and value women's work in the same way as men's work?

\section{Origins, objectives, and involvement of women's groups in enhancing wellbeing}

The original activities of women's fishing community groups, starting in the 1950s, focused on reducing expenses and taking care of families and communities. An early strategy, initiated by women in Hokkaido, was to reduce the costs of traditional ceremonies, such as birthdays, marriages, funerals, and ancestral worship. This strategy was so successful that it was adopted in many other locations throughout Japan. This led to the establishment of more women's fishing community groups. Membership in these groups was voluntary, and the groups focused on social tasks in the households and the communities. This set clear gender roles for women in fishing communities, many of which are still seen today.

Over time, new types of objectives and actions have been developed for women's fishing community groups, such as environmental conservation, promotion of fish consumption, and ensuring social cohesion in the communities. During the 1980s, women's groups raised money to support orphans of fishers who had drowned or who had had accidents at sea. Such activities can also be found in other countries, for example, in Europe (Frangoudes et al. 2013).

Women's roles also adapted to changing demographics. As the population of the fishing communities aged, women began to spend more time helping their elders. In many communities, elder care became the main activity of women's groups. This could include shopping, helping with bills or other obligations, and organizing lunch parties and gymnastic activities. FCA women's groups were heavily engaged in supportive activities when the great earthquake hit East Japan in 2011 (Seki 2015). This meant that FCA women's groups wereand still are - constantly participating in the quotidian activities and problems of fishing community residents.

\section{Environmental conservation}

The industrialization and urbanization of the country between 1950 and 1970 had negative effects on the quality of coastal environments and ecosystems with pollution from factories, as well as from domestic waste. Many fishing grounds were destroyed in this period, and women were often at the forefront of protests (McKean 1981). One of the most well-known actions carried out by women's groups, started in the mid1970s involving the protection of the coastal ecosystem and environment. In Japanese fishing culture, there is a shared belief that fishing activities take place through the blessing of nature. As a result, a sense of respect for nature is evident in religious beliefs and is celebrated in community festivals. Activities that conserve stocks and marine ecosystem are part of this traditional belief and still continue, thanks in no small part to women's groups (Seki 2009).

Women's groups have participated in several different types of conservation activities throughout the years. One activity conducted by women groups in this area was raising awareness about the use of detergents in households. In 1975 , during a national meeting, women's groups launched a campaign to abolish harmful synthetic detergents. From this time on, women's groups have promoted the use of natural soaps instead of detergent soaps to protect the coastal environment and ecosystem. This action was inspired by an earlier environmental conservation movement that was initiated in 1966 "linking forests, rivers and the sea" (Seki 2009). In 2000, women's groups broadened their activities to include other environmental actions, such as conducting shore cleanups. Women's groups began picking up litter along beaches and in fishing ports. Today, university and high school students are now invited to help the aging women members with these clean-up events. Another expanding activity conducted by women's groups has been the planting of trees in the mountains. This activity is based on the idea that mountains protect the marine environment and fish (Seki 2009) and on the belief that forests supply various nutrients from the land via rivers to the sea and thus protect the habitats and marine resources. The motivation for all these activities is the conservation of fishing resources and the livelihoods of the households. All these activities that women participate in are voluntary and are not well recognized by society. Indeed, women are often feel discouraged, for example when trash rapidly covers the beaches again, soon after they have done a clean-up. 


\section{Promoting fish consumption from 1985 and onwards}

In response to declining fish consumption in Japan, FCA women's groups have engaged in promoting fish consumption. For example, women teach school children and university students how to cut and cook fish. Women also promote fish products that they produce themselves. Processed products are sold at festivals to encourage fish consumption. For the women's groups, processing seafood is also a way to revitalize their own community (Fujii 2009). Moreover, the processing of fishery products is acknowledged as an important activity, because it serves as a touchstone for the improvement of women's status in the community. In this way, women's groups have become the main promoters of local fishery products.

\section{FCA women groups: membership, actions, and loss of influence}

Women's fishing community groups bring together spouses of FCAs' regular members as well as women living in fishing communities without direct relations with fisheries, but who nevertheless support the aims and activities of the women's groups.

Since 1986, women's groups have changed their objectives and their activities. They now promote women's rights with the aim of achieving "equality between men and women, women's empowerment and creation of upbeat, homey and wealthy fishing communities" (decision of the National Federation of Women Groups associated to the FCAs). In order to reach such objectives, women's groups have promoted the idea of women's participation in FCA decision-making. The groups have gained a strong capacity for lobbying through interactions with the government and the FCAs. While the needed changes are clear to the women's group members, they have not yet achieved their main target, namely participation to the decision-making.

Local women's groups are now found in 35 prefecture groups, organized in a National Federation of Women's Groups associated with the FCAs. However, one of the greatest challenges is the decreasing number of groups and members. In 1990, there were 1391 women's groups and 155,004 members; in 2019, there were only 618 women's groups and 32,051 members. This decline can be explained by the lack of young members and the decision of older women to stop participating or becoming dormant members of the groups. Interviews point to a few additional reasons: for example, the fact that young women do not enjoy the activities run by women's groups and do not feel obliged (as in the past) to be part of these groups. Another reason is that the board members of some FCA women's groups hold on to their position and will not let younger women take over. Finally, women's groups are dominated by wives of powerful fishers and other women feel excluded. Fortunately, such obstacles do not exist in all groups and some are even made up exclusively of young women.

Another element which weakens the position of women's groups within the communities is the lack of participation in decision-making processes regarding women's rights as well as the future of fishing communities. This, despite the 4 th Basic Plan for Gender Equality (2015) promoting the appointment of women as board members of FCAs, gave women better opportunities to participate in decision-making of FCAs but for the moment, it is still not implementing.

In addition to the Plan for Gender Equality, the "Seashore Revitalization Plans"(2014), one of a central pillar of Japanese fisheries policy, were also introduced in 2014(Fisheries Agency 2013). These plans put an emphasis on local community development, a domain in which FCAs have competencies. Thus, FCAs were designated as the institutions to implement these plans and to integrate women into new activities. The hope was to increase the income from fishing by at least $10 \%$ over a 5 -year period through voluntary initiatives. Measures to add value to the fish catch included processing, the creation of new products, or selling to new markets. Women's groups already had experiences in processing and creating new products and their participation in the development of these plans could provide new ideas. However, interviews conducted at a local level showed that either women were not invited by FCAs or did not respond to their requests. A variety of reasons can explain women's absence including cases where FCAs did not inform women about these plans and the content, other cases where aging women did not have the time or the motivation to participate, or cases where women had not been able to prepare and implement community revitalization plans. This is disappointing as the survival of fishing communities and organizations depends on the integration of younger generations in the communities.

Young people in communities are the targets for the "revitalization plans" and a vital part of increasing fisheries incomes. New economic activities may attract new inhabitants, especially in remote areas. However, regular members of the FCAs are rarely willing to share responsibilities with the newcomers and particularly women who would like to participate in the community development. There are examples where women's groups and FCAs marginalize women who attempt to take on new initiatives to promote the communities (see example of Nori Group below).

\section{Women's entrepreneurial groups}

In 2010, 364 entrepreneurial groups existed in Japan (Tokyo Fisheries Promotion Foundation; Umi Hito Kurashi Forum; Co., Ltd Fishing Communities Planning, 2011). The majority of these entrepreneurial groups are independent, with only a 
few being related to FCAs. For a better understanding of the activities and the nature of "women's entrepreneurial groups" and their territorial linking, we illustrate two examples of women's groups which we call "Nori Group" and "Fish Group."

Nori Group was created painstakingly in 2010 by women in a coastal community who work together on laver (nori) seaweed aquaculture. When women started this business, they intended to use blemished dried laver seaweed to increase the reputation of local product. The 52 women who established this entrepreneurial group were members of a FCA women's group. All of them were convinced that the dried seaweed produced from their area tasted good, but the price was low due to minor blemishes. At the time the group was established the price of seaweed, especially the slightly blemished dried laver, had fallen significantly. As the price continued to decrease, one after another of the women abandoned the group. The remaining 17 members decided to continue this activity without the support of the FCA. In 2013, they started an independent entrepreneurial group. At present, four members organize this group, and they employ four part-time women employees.

These remaining women have made great efforts to find new markets to sell their products, including Tokyo department stores. Currently, their flagship product is laver seaweed simmered into a paste of soy sauce and other ingredients. Traditionally, this kind of seaweed is eaten with rice. The women in Nori Group have suggested various other ways of eating it, for example, with pasta, to widen their product's appeal. Currently they have shifted from selling to the national market, and are instead expanding to an international export market. Their products have a good reputation and their entrepreneurialism is among the best of Japanese fisheries women's groups.

The Nori Group has had to overcome a considerable number of obstacles over the years. This has included disagreements with the local FCA and its male members. Initially the Nori Group paid to use the FCA factory for product processing. Fishermen and FCA board members were unhappy with the women's group using the FCA facilities and did not sympathize with or recognize a women-led business and its success. However, when the enterprise finally appeared successful and reached some level of stability, the attitude and behavior of the FCA changed. Now the men of the FCA recognize the skills of the Nori Group members and will ask them to collaborate on projects. Currently the Nori Group has a business relationship with the FCA. The activities of the Nori Group have clearly exerted an impact on the FCA.

Fish Group was initially connected to their FCA. They run and restaurant and produce prepared meals using local fish. As the population of the community aged, women noticed that elderly people were having difficulties shopping and cooking without assistance. The women's fishing community group thought that if they processed and sold low value fish, caught by local fishers, it would help to increase fishers' incomes. If they also prepared and sold lunch boxes using the same fish and delivered them directly to elderly people's houses, they would contribute to community wellbeing.

The women moved rapidly into action and started their project in 2006. According to by-laws, the leadership of the group had to change every second year on a rotational basis. Initially, all 194 members of the FCA women's group were involved in the project. However, the leader rapidly discovered major differences between the members' cooking skills. In addition, the principle of rotating leadership turned out to be an obstacle to the development of the project, since the capacity, qualifications, and abilities among members also varied greatly.

One year later, in 2007, the leader organized a new independent group, separate from the FCA. In the new Fish Group, members came up with investment capital themselves. About 42 investors joined the new group with a board of five members who were also engaged in the business. Today, the Fish Group employs about 30 local women. They utilize local fish and labor resources. The restaurant run by the Fish Group is another activity and has its own employees. The Fish Group and its branches are very well known for its Japanese horse mackerel dishes, which is unique in Japan. The leader of the group received an award from the emperor of Japan for their activities.

\section{Women in fisheries communities: contributions and obstacles to being regular members of FCAs-further discussions}

National fisheries authorities expect women to lead the economic development of their communities. To meet this expectation, many women in various regions of Japan have created women's fisheries entrepreneurship groups in order to add value to fish. At the moment, annual sales are small, on average about 3 million yen (US\$28,000). Thus, these businesses are generally small-scale enterprises. Fisheries officers and male scientists often characterize these small enterprises run by women as "just women's fun." However, this is far from the truth. Firstly, women's entrepreneurial groups use local fish with low commercial value, which would otherwise be discarded. This type of fish gives a value of about 1 billion yen (US\$ 9,395,000), in other words, each of the 364 groups represents a value of US\$28,000 (Soejima and Makino 2018). The impact of such activities on the national economy is difficult to evaluate, but for women it is significant, not only on a financial level but also for women's empowerment and gender equality.

According to our analysis, women's entrepreneurship groups face three main problems. Firstly, leaders are 
overworked, since they are very committed to success of these businesses. Thus, they put a lot of effort and pride in using local fish, and serving their local community through feeding the elderly. In this way, they contribute to local fishing and to creating a viable community. The leaders are in a situation involving physically and psychologically demanding circumstances, but they continue and are able to withstand these demands.

Secondly, the businesses are marginal and are less lucrative than other businesses. Therefore, young women often choose to work in other industries and not in the women's groups. Consequently, the groups suffer from a lack of young labor.

Thirdly, women's efforts are not recognized as important in supporting fisheries in local communities. For example, the woman leading Fish Group was also leading the FCA fisheries women's group (from 2005 to 2017) and the National Federation of FCAs women's groups (from 2015 to 2017). She advocated for women rights at different events at local, prefecture, and national levels and lobbied for women's recognition. When she requested to become a regular FCA member, she was rejected. This negative response can be interpreted as gender discrimination. According to the Fisheries Cooperative Association Law, to be "a regular member," you should reside "within the district of the cooperative in question, engage in a fishery business, or engage in fishery work during a certain number of days, decided upon by the association, i.e., 90 to 120 days during a single year." Only if applicants meet these basic criteria can they become a regular member. In theory, these rules allow women to become regular members of the cooperative because the word "fishing" is not limited to work at sea, but also implies work on land. So women working on land could apply for membership. However, the number of women members of cooperatives (women members are 7679 of 134,570 total members in 2017: Fisheries Cooperative Association Statistics) shows that local cooperatives still set as a main condition the number of days spent at sea. Therefore, in practice, this condition excludes women working on land and only allows women working in fisheries harvesting (shellfish or seaweed) to be members. Even women working in partnership with their spouses-husband-and-wife fishing operations-are perceived as helpers and are not allowed to become regular members of FCA. For these reasons, in 2017, only 51 women out of 9330 were found sitting on FCAs' boards. This number represents $0.5 \%$ of the total board members. It is clear that FCAs and their decision-making bodies continue to be dominated by men and exclude women.

Across Japan, most women who qualify for regular membership do not become regular members. One of the reasons for this situation is the entrenched rule of one member per household. This not only excludes women, but also younger fishers. For example, male fishers who have not fished the required number of days can retain their membership status, while younger full time fishers are unable to join because of attempts to limit the number of new members. In addition, a large fee has to be paid to become a regular member of an FCA. The payment of this fee prevents women and young men from applying for FCA membership especially as being a member does not guarantee a higher income.

Probably the main factor preventing women from being regular FCA members is that their contribution to fisheries is not recognized. Fisheries laws have until now not recognized women's invisible contribution to the fisheries industry. Many women in fishing communities carry out work on land, as shore or ground crew (Gerrard 1995) but without the benefit of legal recognition, as for example is the case in France with the collaborator spouses' status (Frangoudes and Keromnes 2008). As a consequence, women's contributions are not formally recognized by society. So, the resistance to women's FCA membership is a cultural issue, since men's work is considered more valuable compared with women's work.

\section{Conclusion}

Women in Japanese coastal communities have been organized and connected to Fishery Cooperative Associations (FCAs) for many years. However, they have not had fullmembership rights because of the Japanese law and the practice of: "one member per household.", which is traditionally reserved for men. The consequence of this practice is FCAs with few women and few younger members, since newcomers are seldom recruited. This membership pattern also prevents renewal of fishing communities' populations. Therefore, FCAs have been less successful in their efforts to improve the wellbeing and viability of fisheries communities.

Seen from a gender perspective, the Japanese cooperatives' first priorities have been the management of marine resources. Up to now, FCAs have been well known for their success in this field. But shifting demographics and gender equity goals have yet to be reflected in FCA membership. Therefore, the situation is that populations that are key to the survival of thriving and sustainable fisheries (young men and women) are excluded for the decision-making process. Instead, elderly men and former fishers that are unable to fish are FCAs' regular members and manage the resources and maintain their influence and power within the FCAs. But for how long? In some FCAs, membership has dropped to a point where the organization cannot be maintained. In some cases, elderly male members have finally decided to allow women to become regular members in an effort to boost membership numbers. These examples show that women are acceptable as regular members only when the FCAs' survival is at stake. However, the structure of FCAs through law and through local men's practices is maintained, the patriarchal system continues - at least for the time being. 
Japanese women continue to contribute to the wellbeing of the household and the viability of the communities through voluntary activities as members of FCA women's groups. The groups have played - and still play - a prominent role in the economy of many fishing communities by connecting local fishing, local processing, local distribution, and local consumption. However, there are signs of changes. Examples of women's entrepreneurship offers hope for renewal and revitalization of fishing communities.

The decline in the population of fishing communities, due to an aging population that is not being replaced, is clearly taking place. In order to keep and develop remote fishing communities, there is an urgent need to restructure the local economy to support these communities. Women's fisheries entrepreneurial groups are trying to respond to these problems. Moreover, the FCA women's groups are not disappearing and they still play an important role in their communities, and in lobbying for the recognition of women invisible contribution to fisheries by changing the patriarchal decision structure that still exists. In order to move forward, the patriarchal vision of FCAs and of official plans and laws must be replaced by policies that serve both women and men. The national fishery plans and laws should aim at revitalizing the communities and entrepreneurship capacities of women and men.

This paper has envisioned the need for women to become full members of FCAs. Women in coastal communities through their group activities have demonstrated their willingness, abilities, and capabilities to aid in renewal. As full members of FCAs, their ideas and the way they are working should be brought into the open, and they should be able to participate in decisions about the future of their fishing communities and FCAs. By including women in formal decision-making processes, they would not only contribute to the wellbeing of households and communities, but also to renewal of more sustainable and viable communities as well as more sustainable fishing and fishery policies. Last, but not least, by continuing to work for the wellbeing of the households and communities, through established, but also through new entrepreneurial activities, women can also strengthen their own identities as recognized coastal and fishery women.

Open Access This article is distributed under the terms of the Creative Commons Attribution 4.0 International License (http:// creativecommons.org/licenses/by/4.0/), which permits unrestricted use, distribution, and reproduction in any medium, provided you give appropriate credit to the original author(s) and the source, provide a link to the Creative Commons license, and indicate if changes were made.

\section{References}

Barret, G., and T. Okudaira. 1995. The limits of fishery cooperatives? Community development and rural depopulation in Hokkaido, Japan. Economic and Industrial Democracy 16: 201-232.
Blau, Peter Michal. 1964. Exchange and power in social life. Transaction: Publishers.

Cabinet Office. 2015. The $4^{\text {th }}$ Basic Plan for Gender Equality. http:// www.gender.go.jp/about_danjo/basic_plans/4th/index.html. Accessed 2 November 2019.

Delaney, A.E., 2003. Setting nets on troubled waters: environment, economics, and autonomy among nori cultivating households in a Japanese fishing cooperative. Ph. D. Dissertation, University of Pittsburgh

Delaney, A.E. 2015. Japanese fishing cooperative associations: governance in an era consolidation. In Interactive governance for small scale fisheries: global reflections, MARE Publications Series, ed. S. Jentoft and Ratana Chuenpagdee, vol. 13, 263-280. New York: Springer.

Delaney, Alyne, and Nobuyuki Yagi. 2018. Implementing the SSF guidelines: lessons from Japan. In The small scale fisheries guidelines, MARE Publication series, ed. S. Jentoft et al., 14th ed., 313-332. https://doi.org/10.1007/978-3-319-55074-9_12.

Fisheries Agency. 2013. FY 2013 trends in fisheries FY 2014 Fisheries Policy White Paper on Fisheries: Summary. http://www.jfa.maff.go. jp/j/kikaku/wpaper/pdf/2013 jfa_wp.pdf.Accessed 20 Nov 2019.

Fisheries Agency. 2017. New Fisheries Basic Plan. http://www.jfa.maff. go.jp/j/policy/kihon_keikaku/. Accessed 2 Novemeber 2019.

Frangoudes, Katia, and Enora Keromnes. 2008. Women in artisanal fisheries in Brittany, France. Development 51: 265-270.

Frangoudes, Katia, José Pascual Fernadez, and Begona Marugan Pintos. 2013. Women's organisations in fisheries and aquaculture in Europe : history and future prospects. In Social issues in sustainable fisheries management, MARE Publications Series, ed. J. Urquhart and G.T. Accott, 215-231. New York: Springer.

Fujii, Wasa. 2009. Training of women leaders in fishing communities: the system for certifying "woman fisheries specialists". In Women in Japanese fishing communities, ed. Hitomi Nakamichi, 88-118. Tokyo: Agriculture and Forestry Statistics Publishing Inc.

Foucault, Michel. 1980. Power/knowledge: selected interviews and others writings. Edited by Colin Gordon. Published by Vintage, $\mathrm{p}$. 288.

Gender Equality Bureau Cabinet Office. 2016. Expansion of women's participation in policy and decision-making process in all fields in society. http://www.gender.go.jp/english_contents/mge/process/ index.html. Accessed 2 November 2019.

Gerrard, S. 1995. When women take the lead: changing conditions for women's activities, roles and knowledge in North Norwegian fishing communities. Social Science Information 34 (4): 593-631.

Kurihara, Syu. 2008a. Kyodo Kumiai Soshiki no Rinen to Gyokyo Undo (Banner of Cooperative Association's Organization and Fisheries Cooperative Association's movement). In Point Seiri de manabu Suisan Keizai [Fisheries economics to learn by sorts out points], ed. Katsuji Hiroyoshi and Sano Masaaki, 263-264. Tokyo: Hokuto shobo.

Kurihara, Syu. 2008b. Gyokyo no Rekishi Sonzai no Tokushitsu (Dimension of Fisheries Cooperative Association's historical extence). In Point Seiri de manabu Suisan Keizai [Fisheries economics to learn by sorts out points], ed. Katsuji Hiroyoshi and Sano Masaaki, 265-266. Tokyo: Hokuto shobo.

Moss Kanter, Rosabeth. 1977. Men and women of the corporations. New York: Basic Books.

Makino, Mitsutaku. 2011. Fisheries management in Japan: its institutional features and case studies, Fish and fisheries series. Vol. 34. London: Springer.

McKean, M.A. 1981. Environmental protest and citizen politics in Japan. Univ of California Press.

Miki, Natsuko. 2010. JF Zengyoren ni tsudou Gyokyo Josei no 50 nen shi (Fifty years' history of Fishery Cooperative Associations' women of national association of fisheries cooperative's women's groups). In Gyokyo Joseiren no Ayumi [ Step up of national association of 
fishery cooperative's women's groups], ed. National Association of Fishery Cooperative's women's groups, 159-253. Tokyo: National association of fishery cooperative's women's groups.

Munk-Maden, Eva. 1998. The Norwegian fishing quota system: another patriarchal construction. Society and Natural Resources 11 (3): 229 240. https://doi.org/10.1080/08941929809381075 (aquired 10.24 2019).

Nakamichi, Hitomi. 2009. The current state of fisheries and the status of women. In Women in Japanese fishing communities, ed. Hitomi Nakamichi, 1-19. Tokyo: Agriculture and Forestry Statistics Publishing Inc.

Radtke L.H., and H.J. Stam, eds. 1994. Power/gender. Social relations in theory and practice. London: Sage Publications.

Ruddle, K., and T. Akimichi. 1984. Maritime institutions in the western Pacific. Seri ethnological studies 17: 1-9.

Radle, H.L., and H.J. Stam. 1994. Power/Gender. Sage, London.

Seki, Izumi. 2009. Women of fishing communities and the environment. In Women in Japanese fishing communities, ed. Hitomi Nakamichi, 119-145. Tokyo: Agriculture and Forestry Statistics Publishing Inc.

Seki, Izumi. 2015. Gyoson Josei Soshiki no doko to sono Kadai ni tsuite (Current and issues of women's groups in fishing community). In Gyogyo/Suisangyo ni okeru Higashi Nihon Daishinsai to Hukko ni kansuru tyosa kenkyu [Report about the Great East Japan Earthquake losses and reconstruction], ed. Katsuji Hiroyoshi, 235-242. Tokyo: Tokyo Fisheries Promotion Foundation.

Soejima, Kumi. 2009. Re-evaluation of work on land and regular membership for women in Gyokyo (fishery cooperatives). In Women in Japanese fishing communities, ed. Hitomi Nakamichi, 59-87. Tokyo: Agriculture and Forestry Statistics Publishing Inc.

Soejima, Kumi and Makino, Mitsutaku. 2018. The development of women fishery entrepreneurship group in the Japanese marine products distribution sector. In Small-scale fisheries in Japan: environmental and socio-cultural perspectives (ebook), ed. Giovanni Bulian, Yasushi Nakano, Italy. Edizioni.

Tokyo Fisheries Promotion Foundation; Umi Hito Kurashi Forum; Co., Ltd Fishing Communities Planning. 2011. Zenkoku Gyoson Josei Group Katsudo Jittai Tyosa Houkokusyo [Report of across-thecountry women's groups' activities situation]. Tokyo: Tokyo Fisheries Promotion Foundation.

Publisher's note Springer Nature remains neutral with regard to jurisdictional claims in published maps and institutional affiliations. 